\title{
Random molecular substructures as fragment-type descriptors
}

José Batista ${ }^{1,2}$

\section{From 5th German Conference on Cheminformatics: 23. CIC-Workshop}

Goslar, Germany. 8-10 November 2009

A novel approach for analysis of structure-activity relationships for sets of active compounds is reported. Molecular similarity relationships are analyzed among compounds with related biological activity based on the evaluation of randomly generated fragment populations. Fragments are randomly generated by iterative bond deletion in molecular graphs and hence depart from those obtained by well-defined fragmentation schemes [1]. A major finding has been that for any given activity class, dependency relationships of fragment co-occurrence exists within random fragment populations. Through the analysis of these relationships the chemical information content of generated substructures can be quantified [2]. This has lead to the identification of small numbers (10- 40) of so-called activity class characteristic substructures (ACCS) that have been successfully utilized in virtual screening applications $[3,4]$.

\footnotetext{
Author details

'Jado Technologies GmbH, Tatzberg 47-51, D-01307 Dresden, Germany ${ }^{2}$ Department of Life Science Informatics, B-IT, LIMES Program Unit Chemical Biology and Medicinal Chemistry, Rheinische Friedrich-Wilhelms-Universtität Bonn, Dahlmannstr. 2, D-53113 Bonn, Germany.
}

Published: 4 May 2010

\section{References}

1. Batista J, Godden JW, Bajorath J: J Chem Inf Model 2006, 46(5):1937-1944, (PMID: 16995724).

2. Batista J, Bajorath J: J Chem Inf Model 2007, 47(4):1405-1413, (PMID: 17585755).

3. Batista J, Bajorath J: Chem Med Chem 2008, 3(1):67-73, (PMID: 17952883).

4. Stumpfe D, Frizler M, Sisay MT, Batista J, Vogt I, Gütschow M, Bajorath J: Chem Med Chem 2009, 4(1):52-54, (PMID: 19053132).

doi:10.1186/1758-2946-2-S1-012

Cite this article as: Batista: Random molecular substructures as

fragment-type descriptors. Journal of Cheminformatics 2010 2(Suppl 1):012

'Jado Technologies GmbH, Tatzberg 47-51, D-01307 Dresden, Germany
Publish with ChemistryCentral and every scientist can read your work free of charge

"Open access provides opportunities to our colleagues in other parts of the globe, by allowing anyone to view the content free of charge." W. Jeffery Hurst, The Hershey Company.

- available free of charge to the entire scientific community

- peer reviewed and published immediately upon acceptance

- cited in PubMed and archived on PubMed Central

- yours - you keep the copyright

Submit your manuscript here:

http://www.chemistrycentral.com/manuscript/

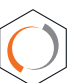
Chemistry Central 